\title{
9 各種繊維へのホルムアルデヒドの残留
}

高島征助（クラレ中央研）

緒言 : 殺菌剤「ホルムアルデヒド (FA)」は，その 強力な殺菌力, 取扱いの簡便さから医療現場で沉用さ れているが，その有害性についての検討例は少ない．

著者はこれまでにFAの血液成分および細胞への影 響, 作業環境中の低減化の方法について報告してきた.

本報では医療現場で使用されている繊維製品の FA の残留挙動を考察するための一方法として，素材別に FAの残留量を経時的に測定した.

実験方法: 現在, 市販されている木綿, 絹, ウール など天然繊維, およびナイロン, ポリエステル, アク リルなど合成㵶維, 合計 10 種類の試験片 $(5 \mathrm{~cm} \times 5 \mathrm{~cm})$ をホルムアルデヒド蒸気が允満しているデシケーター 中で室温にて一夜曝露した. デシケーターから取り出 した試験片を所定時間 (0，1，2，4 時間) 後に蒸留水 中に浸漬し, 試験片から水中に移行した FA 量から元
の試験片の残留量を算出した.

また同様に FA 処理した試験片を, $40^{\circ} \mathrm{C}, 60^{\circ} \mathrm{C} の$ 雾囲気に所定時間 (1，2，4 時間）放置した際の FA 残留量も測定した.

$\mathrm{FA}$ 濃度測定法 : 比色法, $\lambda \max , 630 \mathrm{~nm}$. (3ーメチル -2-ベンゾチアゾロン法)

実験結果および考察：一般的傾向として, 合成紪維 よりも天然繊維の方が FA は残留し易いことが明らか になった。

医療現場, とくに患者用の寝具類の清潔管理に FA が使用されることもあるが，それら恃主に天然繊維で 構成されている.

したがって寝具類をで殺菌消毒処理を行う際には， FA 残留量の低減化について何らかの対策を講ずる必 要がある.

\section{0 医療用不織布ガウンの防水性と着用快適性について}

大久保 憲 (刈谷総合病院手術部), 宮守健一, 野崎 哲 (ユニ・チャーム) 戸川友幸，松野士郎（森下製薬）

はじめに: 従来の撥水不織布は, 防水性に関しては 完全なもので㤬なく，一定レベル以上の加圧下では血 液などが透過する可能性があった. 今回, 多孔質ポリ オレフィンフィルムを完全防水層として使用した新し い素材による手術用ガウンについて，手術中に衣服内 の温度・湿度を連続測定し, 衣服内気侯を検砷したの で報告する.

方法：特定の被検者 1 名に扔いて，手術時間90分以 上の全身麻酔手術症例について, 術者のアンダーウエ アーのポケットに超小型データロガ (JMS 社製 XT102 型）を設置し, ガウン内の温度・湿度を連続的に 測定した. あわせて環境の温度・湿度の変化について も測定した. 使用した素材は, 木綿, スパンレース不 織布, ポリオレフィンフィルムとスパンレース不織布 とのコンポジット不織布 (以下コンポジット不織布) である.

結果：いずれの素材においても，手術執刀10分前か ら執刀後30分にかけてガウン内の温度・湿度は急激に
上昇した、木綿製は温度変化のレベルが最も低く、コ ンポジット不織布はわずかに高いレベルであった・ス パンレース不織布は温度変化パターンにおいて木綿製 と類似していたが、コンポジット不織布は木綿製に比 較し多少異なっていた. 一方, ガウン内湿度は木綿製 が最も低く, 湿度がこもらないパターンであり, コン ポジット不織布製ガウンで湿度がやや高い傾向にあ ったが，実用上の着用感に支障は認められなかった。

考察: 手術用ガウンはバクテリアバリアー性からみ ても完全防水性が望まれるが，着用快適性から考えた 場合, ある程度の通気性と透湿性を確保しなければな らない。したがって多数の微細な孔を有する撥水性の 高いシートを素材の中間層に使用したコンポジット不 織布注, 防水性において従来の素材に比べて優ってお り, 着用快適性の面では実用レベルで従来品と同程度 であり，手術用ガウンの素材として有用性の高いもの と考えられる。 